IQTISHODUNA

Vol. 16 (2), 2020

P-ISSN: 1829-524X, E-ISSN: 2614-3437

\title{
Keputusan Pembelian Dipengaruhi oleh Kesadaran, Kualitas, Asosiasi dan Loyalitas Merek Melalui Kepercayaan Merek Kamera Sony Pada Komunitas Fotografi di Malang
}

\author{
Tri Sugiarti Ramadhan1, Eka Farida ${ }^{2 *}$ \\ Universitas Islam Malang, Indonesia
}

*Corresponding Author:
E-mail: arida@unisma.ac.id

\begin{abstract}
The purpose of this study was to determine and analyze purchasing decisions that are influenced by brand awareness, quality, association, and loyalty through brand trust. This type of research is a causal relationship with an explanatory character. The population in this research is the photography community DSLR (Digital Single Lens Reflex) camera users in Malang, East Java, totaling 190 respondents. The sampling technique used in this study was purposive sampling technique with a total sample of 66 respondents. The analysis used is path analysis, and the results show that purchasing decisions are influenced by brand awareness, quality, association, and loyalty through brand trust. The results showed that purchasing decisions are influenced by awareness, quality, association, and brand loyalty through brand trust.
\end{abstract}

Keywords: purchasing decisions, awareness, quality, associations, brand loyalty and brand trust.

\begin{abstract}
Abstrak: Tujuan penelitian ini untuk mengetahui dan menganalisis keputusan pembelian yang dipengaruhi oleh kesadaran, kualitas, asosiasi, dan loyalitas merek melalui kepercayaan merek. Jenis penelitian ini adalah hubungan kausal (cause-effect relationship) bersifat eksplanasi (explanatory). Populasi dalam penelitian ini adalah pengguna kamera DSLR (Digital Single Lens Reflex) komunitas fotografi di Malang, Jawa Timur yang berjumlah 190 responden. Teknik pengambilan sampling yang digunakan dalam penelitian ini adalah teknik purposive sampling dengan jumlah sampel sebanyak 66 responden. Analisis yang digunakan adalah analisis jalur, dan hasil penelitian menunjukkan bahwa keputusan pembelian dipengaruhi oleh kesadaran, kualitas, asosiasi, dan loyalitas merek melalui kepercayaan merek. Hasil penelitian menunjukkan keputusan pembelian dipengaruhi oleh kesadaran, kualitas, asosiasi, dan loyalitas merek melalui kepercayaan merek.
\end{abstract}

Kata kunci: keputusan pembelian, kesadaran, kualitas, asosiasi, loyalitas merek, dan kepercayaan merek. 


\section{Cara mencitasi:}

Ramadhan, T.S. \& Farida, E. (2020). Keputusan Pembelian Dipengaruhi oleh Kesadaran, Kualitas, Asosiasi dan Loyalitas Merek Melalui Kepercayaan Merek Kamera Sony Pada Komunitas Fotografi di Malang. Iqtishoduna, 16 (2), 131-146.

\section{Pendahuluan}

Pengembangan kamera diera globalisasi berkembang dengan begitu pesat, misalnya tingkat kualitas megapixel yang mampu menghasilkan kualitas gambar yang jauh lebih bagus dan sensor kamera yang lebih detail. Secara kualitas dan kecanggihan, kamera saat ini memiliki kecanggihan yang jauh lebih bagus dari edisi kamera sebelumnya. Fungsi dari kamera sekarang bukan hanya dipergunakan untuk kepentingan perseorangan, tetapi juga digunakan untuk kegiatan observasi, riset, dan penunjang gaya hidup generasi milenial. Kokasih $d k k$. (2013) menyatakan bahwa nilai aset perusahaan dan persaingan merupakan faktor pentingnya peranan brand bagi perusahaan kamera. Sedangkan Sholahuddin (2013) mengungkapkan seorang konsumen akan mengenal brand kamera dari apa yang dia dengar baik dari media online ataupun dari orang disekitarnya. Sehingga equity mampu menjelaskan makna dari sebuah brand kamera.

Keputusan pembelian akan dipengaruhi oleh rasa percaya diri konsumen dalam menilai brand equity kamera (Rofiq, 2005). Dan dari beberapa kajian empiris diantaranya penelitian yang sudah dilakukan oleh Santoso \& Harmoni (2016) menunjukkan adanya pengaruh ekuitas merek terhadap keputusan pembelian Smartphone Samsung; (2) Siali dkk. (2016) dengan hasil penelitian Relationship Between Brand Equity And Consumer Purchase Decision: A Case Of An International Brand Of Footwear; dan (3) Widhiarta \& Wardana (2015) menyatakan bahwa ekuitas merek berpengaruh terhadap keputusan pembelian iphone di Denpasar. Delgado (2014) mengungkapkan alasan penting menentukan merek kamera yang digunakan adalah berdasarkan dari kepercayaan konsumen terhadap merek tersebut.

Dengan demikian dapat dinyatakan bahwa keputusan pembelian kamera oleh konsumen sangat dipengaruhi oleh kepercayaan dan ekuitas 
merek, maka penelitian ini bertujuan untuk meneliti komunitas fotografi kamera Sony di Malang. Pemilihan komunitas tersebut sebagai responden penelitian dikarenakan mereka adalah pengguna kamera DSLR (Digital Sigle Lens Reflex). Tujuan dari penelitian ini adalah untuk mengetahui dan menganalisis (1) ada atau tidaknya pengaruh kesadaran terhadap keputusan pembelian melalui kepercayaan merek; (2) ada atau tidaknya pengaruh kualitas terhadap keputusan pembelian melalui kepercayaan merek; (3) ada atau tidaknya pengaruh asosiasi terhadap keputusan pembelian melalui kepercayaan merek; dan (4) ada atau tidaknya pengaruh loyalitas merek terhadap keputusan pembelian melalui kepercayaan merek.

\section{Kajian Pustaka}

\section{Keputusan Pembelian}

Keputusan pembelian menurut Drumond (2003) adalah mengidentifikasikan semua pilihan yang mungkin untuk memecahkan persoalan itu dan menilai pilihan-pilihan secara sistematis dan obyektif serta sasaran-sasarannya yang menentukan keuntungan serta kerugiannya masing-masing. Sedangkan Nugroho (2011) keputusan pembelian adalah proses pengintegrasian yang mengkombinasi sikap pengetahuan untuk mengevaluasi dua atau lebih perilaku alternatif, dan memilih salah satu diantaranya. Keputusan pembelian yang diambil oleh pembeli sebenarnya merupakan kumpulan dari sejumlah keputusan yang terorganisir. Sumarni (2010) menyatakan setiap keputusan pembelian mempunyai struktur sebanyak tujuh komponen meliputi jenis, bentuk, merek, penjualan, jumlah, waktu pembelian, dan cara pembayaran. Pada umumnya manusia bertindak rasional dan mempertimbangkan segala jenis informasi yang tersedia dan mempertimbangkan segala sesuatu yang bisa muncul dari tindakannya sebelum melakukan sebuah perilaku tertentu para pemasar harus melihat lebih jauh bermacam-macam faktor yang mempengaruhi para pembeli dan mengembangkan pemahaman mengenai cara konsumen melakukan keputusan pembelian.

\section{Kesadaran}

Kesadaran merek adalah kemampuan pelanggan untuk mengenali dan mengingat kembali sebuah merek dan mengaitkannya dengan suatu produk tertentu. Kesadaran Merek memiliki tingkatan dalam ingatan konsumen dalam menciptakan suatu nilai. Menurut Aaker (2013) tingkatan kesadaran meliputi (a) top mind menggambarkan merek yang pertama kali diingat oleh 
responden atau pertama kali disebut ketika yang bersangkutan ditanya tentang suatu kategori produk; (b) brand recall (pengingatan kembali merek) mencerminkan merek-merek apa yang diingat responden setelah menyebutkan merek yang pertama kali disebut; (c) brand recognition (pengenalan) merupakan pengukuran brand awareness responden dimana kesadarannya diukur dengan memberikan bantuan pertanyaan yang diajukan dibantu dengan menyebutkan ciri-ciri dari produk merek tersebut (aided question).

\section{Kualitas}

Kualitas yang dirasakan (Perceived Quality) terhadap merek menggambarkan respon keseluruhan pelanggan terhadap kualitas dan keunggulan yang ditawarkan merek. Karena perceived quality merupakan persepsi dari pelanggan maka perceived quality tidak dapat ditentukan secara objektif, persepsi pelanggan akan melibatkan apa yang penting bagi pelanggan karena setiap pelanggan memiliki kepentingan yang berbeda-beda terhadap suatu produk atau jasa. Durinto $d k k$. (2011) menjelaskan beberapa hal yang perlu diperhatikan dalam membangun perceived quality adalah komitmen terhadap kualitas, budaya kualitas, informasi masukan dari pelanggan, sasaran/standar yang jelas, dan membangkan karyawan yang berinisiatif.

\section{Asosiasi}

Asosiasi berkenaan dengan segala sesuatu yang berkaitan dengan memory pelanggan terhadap sebuah merek. Karena itu dalam asosiasi merek menurut Temporal dlam Deka $d k k$. (2019) supaya benar-benar bisa menonjol diantara merek-merek lainnya suatu merek harus mempunyai hubungan emosional yang unik. Pada umumnya asosiasi merek yang membentuk brand image menjadi pijakan konsumen dalam keputusan pembelian dan loyalitasnya pada merek tersebut. Dalam prakteknya banyak sekali asosiasi dan variasi dari brand association yang dapat memberikan nilai bagi suatu merek, dipandang bagi sisi perusahaan maupun dari sisi pengguna berbagai fungsi asosiasi.

\section{Loyalitas}

Loyalitas adalah komitmen kuat dalam berlangganan atau membeli kembali suatu merek secara konsisten di masa mendatang. Konsumen yang loyal berarti konsumen yang melakukan pembelian secara berulang-ulang terhadap merek tersebut dan tidak mudah terpengaruhi oleh karakteristik produk, harga dan kenyamanan para pemakainya ataupun berbagai atribut 
lain yang ditawarkan oleh produk merek alternatif. Dengan pengelolaan dan pemanfaatan yang benar, loyalitas merek menjadi aset strategis bagi perusahaan. Secara umum, langkah-langkah untuk memelihara dan meningkatkan brand loyalty adalah dengan melakukan pemasaran hubungan (relationship marketing), pemasaran frekuensi (frequency marketing), pemasaran keanggotaan (membership marketing) dan memberikan hadiah (reward) (Aaker, 2013).

\section{Kepercayaan}

Kepercayaan pelanggan pada merek (Brand Trust) didefinisikan sebagai keinginan pelanggan untuk bersandar pada sebuah merek dengan risikorisiko yang dihadapi karena ekspetasi terhadap merek akan menyebabkan hasil yang positif (Tjahyadi, 2006). Kepercayaan cukup penting dalam relational exchange. Sedangkan Morgan \& Hunt (2004) menyatakan kepercayaan merupakan cornerstone of the strategic partnership karena karakteristik hubungan melalui kepercayaan sangat bernilai yang mana suatu kelompok berkeinginan untuk menjalankan komitmen terhadap dirinya atas hubungan tersebut. Kepercayaan merupakan harapan dari pihak-pihak dalam sebuah transaksi, dan risiko yang terkait dengan perkiraan dan perilaku terhadap harapan tersebut. Kepercayaan memiliki peran yang penting dalam pemasaran industri.

\section{Pengembangan Hipotesis}

Dalam penelitian ini akan mengukur besarnya pengaruh kesadaran $\left(\mathrm{X}_{1}\right)$, kualitas $\left(\mathrm{X}_{2}\right)$ asosiasi $\left(\mathrm{X}_{3}\right)$, loyalitas $\left(\mathrm{X}_{4}\right)$ terhadap variabel keputusan pembelian (Y) melalui variabel kepercayaan merek (X5). Sehingga dalam penelitian ini terdapat 4 hipotesis yang akan diuji yaitu:

H1. Terdapat pengaruh kesadaran terhadap keputusan pembelian melalui kepercayaan merek.

H2. Terdapat pengaruh kualitas terhadap keputusan pembelian melalui kepercayaan merek.

H3. Terdapat pengaruh asosiasi terhadap keputusan pembelian melalui kepercayaan merek.

H4. Terdapat pengaruh loyalitas terhadap keputusan pembelian melalui kepercayaan merek.

Berdasarkan pengembangan hipotesis yang telah dikemukakan, maka dapat dibuat suatu kerangka konsep penelitian yang menjadi landasan dalam penelitian ini, yang pada akhirnya akan dapat diketahui variabel mana yang 
paling berpengaruh dominan dalam keputusan pembelian konsumen. Kerangka pemikiran ini dapat digambarkan sebagai berikut:

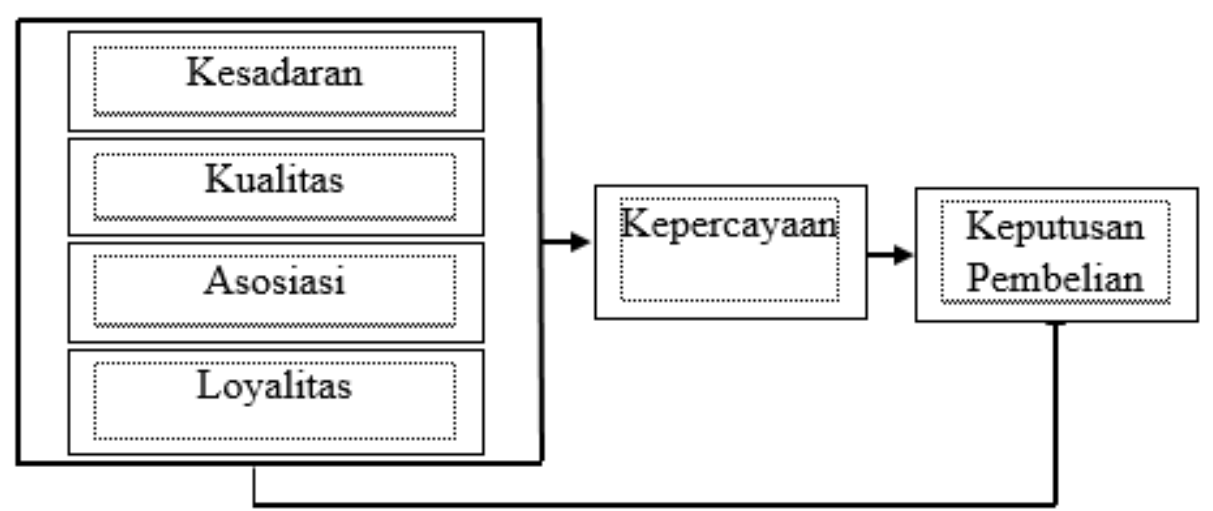

\section{Gambar 1. Kerangka Konseptual Penelitian}

\section{Metodologi Penelitian}

Rancangan penelitian yang digambar dalam penelitian ini adalah hubungan kausal bersifat eksplanasi. Penelitian ini menjelaskan pengaruh kesadaran, kualitas, asosiasi, loyalitas merek, dan kepercayaan merek terhadap keputusan pembelian. Variabel dalam penelitian ini dikelompokan menjadi 6 variabel yaitu: (a) Kesadaran $\left(\mathrm{X}_{1}\right)$, Kualitas $\left(\mathrm{X}_{2}\right)$, Asosiasi $\left(\mathrm{X}_{3}\right)$, dan Loyalitas Merek $\left(\mathrm{X}_{4}\right)$ sebagai variabel bebas; (b) Kepercayaan Merek ( $\left.\mathrm{X}_{5}\right)$ sebagai variabel intervening; dan Keputusan Pembelian (Y) sebagai variabel terikat.

Metode pengambilan sampel yang digunakan dalam penelitian ini adalah metode non random sampling, yakni purposive sampling. Jadi Populasi dalam penelitian ini adalah seluruh pengguna kamera Sony DSLR pada komunitas fotografi di Malang yang berjumlah 190 orang. Penentuan jumlah sampel yang diambil dari populasi penelitian menggunakan rumus Slovin (Amirin, 2011) yaitu, sebagai berikut:

Rumus slovin

$$
\begin{aligned}
& \mathrm{n}=\frac{N}{1+N(e) 2} \\
& n=\frac{190}{1+190(10 \%)^{2}}
\end{aligned}
$$


Berdasarkan rumus Slovin, maka diperoleh responden 65,52 jika dibulatkan menjadi 66 responden. Pengumpulan data dilakukan menggunakan kuesioner, observasi, penelitian kepustakaan, dan wawancara.

Untuk menguji pengaruh variabel intervening, digunakan metode analisis jalur. Analisis jalur (Path Analysis) merupakan pengembangan dari analisis regresi, sehingga analisis regresi dapat dikatakan sebagai bentuk khusus dari analisis jalur (regresion is special case of path analysis) (Sugiyono, 2011). Analisis jalur digunakan untuk melukiskan dan menguji model hubungan antar variabel yang berbentuk sebab akibat (bukan bentuk hubungan interaktif atau reciprocal). Sementara definisi operasional variabel merupakan suatu definisi yang diberikan kepada suatu variabel dengan memberi arti atau menspesifikkan kegiatan atau membenarkan suatu operasional yang diperlukan untuk mengukur variabel tersebut (Sugiyono, 2011). Data dalam penelitian ini akan dianalisis dengan mengggunakan analisis deskriptif dan analisi jalur (path analysis). Untuk melakukan analisis data tersebut akan digunakan bantuan program SPSS for Windows versi 19. Solimun (2002), dalam analisis jalur terdapat beberapa langkah sebagai berikut: (1) merancang model berdasarkan konsep dan teori; (2) pemeriksaan pada asumsi yang melandasi; (3) pendugaan parameter atau perhitungan koefisien path; (4) pemeriksaan validitas model; dan (5) melakukan interpretasi hasil analisis.

\section{Hasil dan pembahasan}

\section{Karakteristik Responden}

Responden yang dijadikan subjek dalam penelitian ini yaitu para pengguna kamera Sony DSLR yang tergabung dalam komunitas fotografi di Malang. Dari hasil penelitian yang dilakukan terhadap 66 responden didapatkan gambaran karakteristik responden meliputi: (1) jenis kelamin, dari 66 responden 56 orang (85\%) berjenis kelamin laki-laki dan 10 orang (15\%) berjenis kelamin perempuan; (2) usia, dari 66 responden 45 orang $(68 \%)$ berusia $17-25$ tahun, 16 orang (24\%) berusia 26-35 tahun, dan 5 orang (8\%) berusia lebih dari 35 tahun; (3) kepemilikan kamera, dari 66 responden 45 orang $(68,2 \%)$ memiliki 1 kamera, 13 orang $(19,7 \%)$ memiliki 2 kamera, 5 orang $(7,6 \%)$ memiliki 3 kamera, dan 3 orang $(4,6 \%)$ memiliki lebih dari 3 kamera; (4) pekerjaan, dari 66 responden 46 orang $(69,7 \%)$ mahasiswa/pelajar, 10 orang $(15,2 \%)$ wiraswasta, 6 orang $(9,1 \%)$ karyawan swasta dan 4 orang $(6,1 \%)$ PNS. 


\section{Keputusan Pembelian}

Variabel terikat keputusan pembelian (Y) dalam penelitian ini menggunakan 4 item pertanyaan. Dari 66 responden, rata-rata paling banyak responden memilih item pertanyaan kedua yaitu keinginan untuk memiliki kamera merek Sony lebih tinggi dibandingkan dengan produk lain. Dan rata-rata paling sedikit responden menjawab item pertanyaan keempat yaitu pengetahuan konsumen tentang spesifikasi kamera Sony.

\section{Kesadaran}

Variabel kesadaran $\left(\mathrm{X}_{1}\right)$ dalam penelitian ini menggunakan 4 item pertanyaan untuk mengetahui tingkat kesadaran konsumen terhadap merek kamera yang mereka ingin beli atau yang sudah dimiliki. Dari 66 orang yang dijadikan sampel dari penelitian ini, rata-rata terbanyak memilih item pertanyaan pertama yaitu sudah mengenali merek kamera Sony. Dan jawaban rata-rata paling sedikit adalah pertanyaan keempat yaitu bentuk, jenis, dan ikon tipe kamera.

\section{Kualitas}

Variabel kualitas $\left(\mathrm{X}_{2}\right)$ dalam penelitian ini adalah penilaian kualitas dari konsumen tentang merek kamera Sony. Dan item pertanyaan yang digunakan dalam variabel ini terdiri dari 4 item pertanyaan. Dari hasil penelitian ratarata terbanyak responden memilih jawaban ketiga yaitu kamera Sony terkenal awet dan tidak mudah rusak. Sedangkan rata-rata terendah responden menjawab item pertanyaan kedua yaitu kamera Sony sudah terkenal memiliki kualitas yang baik dengan harga yang berkelas.

\section{Asosiasi}

Variabel asosiasi $\left(\mathrm{X}_{3}\right)$ yang digunakan dalam penelitian ini terdiri dari 4 item pertanyaan. Variabel asosiasi diajukan untuk mengetahui lebih detail tentang asosiasi merek Sony bagi komunitas fotografi di Malang. Hasil penelitian rata-rata terbanyak memilih jawaban dari pertanyaan pertama yaitu hasil pemotretan memiliki kualitas gambar yang lebih bagus. Dan ratarata jawaban terendah mereka memilih pertanyaan kedua yaitu bentuik desain kamera selalu konstan.

\section{Loyalitas Merek}

Variabel loyalitas merek $\left(\mathrm{X}_{4}\right)$ dalam penelitian ini terdiri dari 4 item pertanyaan. Keempat item pertanyaan yang diajukan bertujuan untuk menggali lebih dalam seberapa tinggi tingkat loyalitas konsumen kamera Sony yang tergabung dalam komunitas pecinta fotografi di Malang. Hasil 
penelitian menunjukkan rata-rata tertinggi memilih jawaban pertama yaitu tetap menggunakan kamera Sony meskipun harganya lebih tinggi dibandingkan dengan kamera merek lainnya. Dan rata-rata jawaban terendah responden memilih jawaban ketiga yaitu tidak terpengaruh dengan merek kamera dari pesaingnya meskipun para pesaingnya mengeluarkan kamera dengan kemampuan yang ditawarkan lebih bagus dari kamera Sony.

\section{Kepercayaan Merek}

Variabel kepercayaan merek $\left(\mathrm{X}_{5}\right)$ dalam penelitian ini sebagai variabel intervening menggunakan 4 item pertanyaan juga. Variabel ini digunakan untuk mengetahui seberapa besar kepercayaan merek dari para pecinta dan pengguna kamera merek Sony. Hasil penelitian menunjukkan sebagian besar menjawab item pertanyaan ketiga yaitu kecanggihan, kualitas, kemampuan, dan hasilnya tidak diragukan oleh konsumen. Dan jawaban terendah memilih jawaban keempat yaitu model dan tipe kamera yang diproduksi mampu memenuhi keinginan konsumen.

\section{Uji Analisis Jalur}

Uji analisis jalur digunakan untuk mengetahui besarnya pengaruh variabel bebas yaitu kesadaran $\left(\mathrm{X}_{1}\right)$, kualitas $\left(\mathrm{X}_{2}\right)$, asosiasi $\left(\mathrm{X}_{3}\right)$, dan loyalitas $\left(\mathrm{X}_{4}\right)$ terhadap variabel terikat yaitu keputusan pembelian $(\mathrm{Y})$ melalui variabel intervening yaitu kepercayaan merek $\left(\mathrm{X}_{5}\right)$.

\section{Tabel 1. Hasil Uji Regresi Linier Berganda}

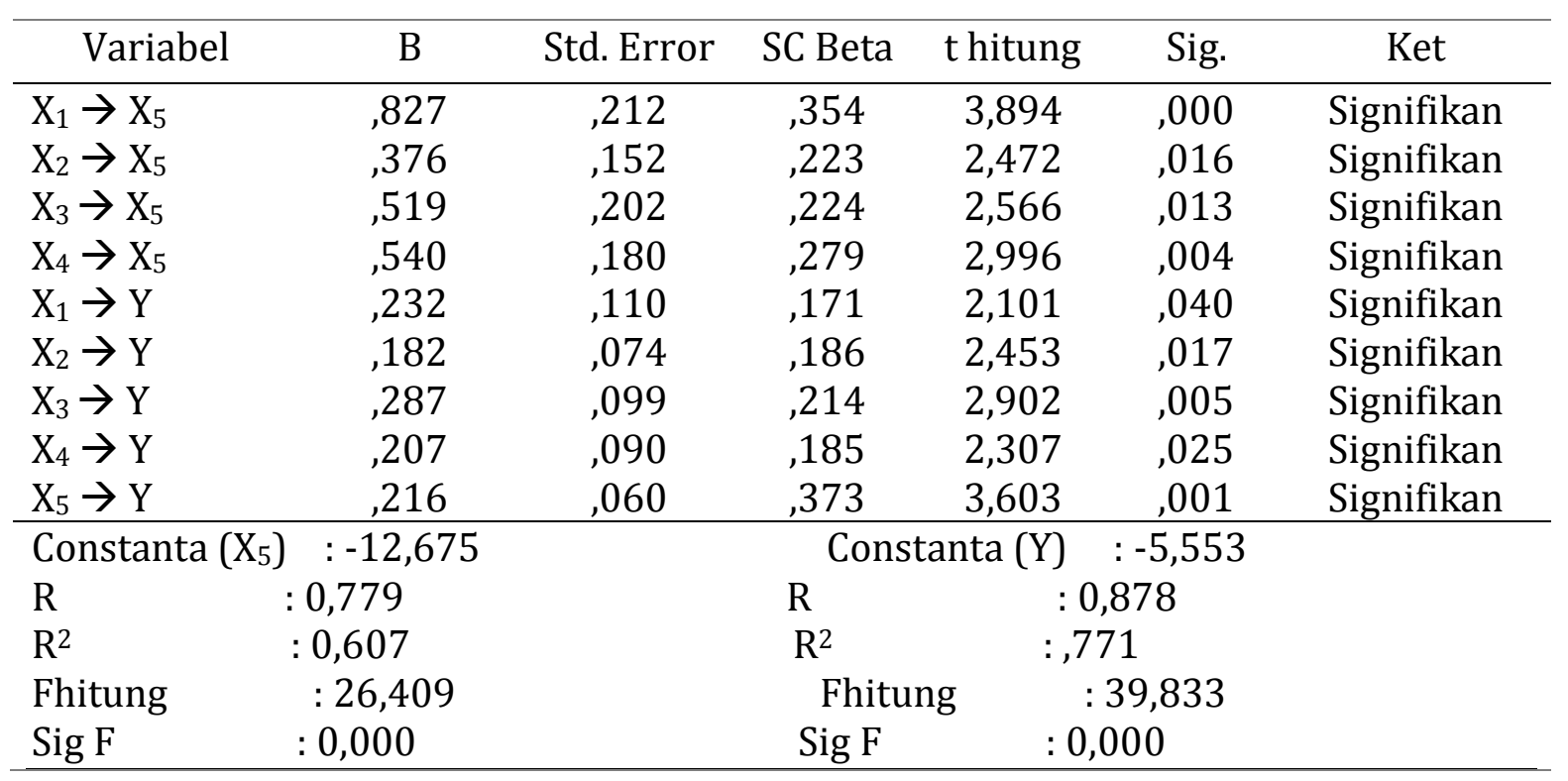


Konstanta (a) = -12,675; menyatakan bahwa jika $\mathrm{X}_{1}$ (kesadaran), $\mathrm{X}_{2}$ (kualitas), $\mathrm{X}_{3}$ (asosiasi), $\mathrm{X}_{4}$ (loyalitas) konstan maka kepercayaan merek akan turun sebesar $1267,5 \%$. Koefisien regresi $X_{1}$ sebesar 0,827 menunjukkan jika kesadaran akan merek mengalami kenaikan sebesar 1\% (satu persen) sedangkan variabel lain konstan, maka kepercayaan merek akan meningkat sebesar $82,7 \%$. Koefisien regresi $\mathrm{X}_{2}$ sebesar 0,376 menunjukkan jika kualitas mengalami kenaikan sebesar $1 \%$ (satu persen) sedangkan variabel lain konstan, maka kepercayaan merek akan meningkat sebesar 37,6\%. Koefisien regresi $\mathrm{X}_{3}$ sebesar 0,519 menunjukkan jika asosiasi mengalami kenaikan sebesar $1 \%$ (satu persen) sedangkan variabel lain konstan, maka kepercayaan merek akan meningkat sebesar 51,9\%. Koefisien regresi $\mathrm{X}_{4}$ sebesar 0,540 menunjukkan jika loyalitas mengalami kenaikan sebesar 1\% (satu persen) sedangkan variabel lain konstan, maka kepercayaan merek akan meningkat sebesar 54\%.

Konstanta (a) = -5,553; menyatakan bahwa jika $\mathrm{X}_{1}$ (kesadaran), $\mathrm{X}_{2}$ (kualitas), $\mathrm{X}_{3}$ (asosiasi), $\mathrm{X}_{4}$ (loyalitas), dan $\mathrm{X}_{5}$ (kepercayaan merek) konstan maka keputusan pembelian akan turun sebesar 553,3\%. Koefisien regresi $\mathrm{X}_{1}$ sebesar 0,232 menunjukkan jika kesadaran mengalami kenaikan sebesar 1\% (satu persen) sedangkan variabel lain konstan, maka keputusan pembelian akan meningkat sebesar 23,2\%.

Koefisien regresi $\mathrm{X}_{2}$ sebesar 0,182 menunjukkan jika kualitas mengalami kenaikan sebesar 1\% (satu persen) sedangkan variabel lain konstan, maka keputusan pembelian akan meningkat sebesar 18,2\%.

Koefisien regresi $\mathrm{X}_{3}$ sebesar 0,287 menunjukkan jika asosiasi mengalami kenaikan sebesar 1\% (satu persen) sedangkan variabel lain konstan, maka keputusan pembelian akan meningkat sebesar 28,7\%.

Koefisien regresi $\mathrm{X}_{4}$ sebesar 0,207 menunjukkan jika loyalitas mengalami kenaikan sebesar 1\% (satu persen) sedangkan variabel lain konstan, maka keputusan pembelian akan meningkat sebesar 20,7\%.

Koefisien regresi $\mathrm{X}_{5}$ sebesar 0,216 menunjukkan jika kepercayaan merek mengalami kenaikan sebesar $1 \%$ (satu persen) sedangkan variabel lain konstan, maka keputusan pembelian akan meningkat sebesar $21,6 \%$.

Berdasarkan model-model pengaruh tersebut pengaruh error ditentukan $\mathrm{P} \varepsilon_{\mathrm{i}}=\sqrt{1-R_{i}^{2}}$, maka $\mathrm{P} \varepsilon_{5}=\sqrt{1-0,607}=\sqrt{0,393}=0,627$ dan $P \varepsilon_{y}=\sqrt{1-0,771}=\sqrt{0,229}=0,479$. Untuk melihat seberapa jauh efek intervening masing-masing variabel intervening dalam konteks hubungan antara kesadaran $\left(\mathrm{X}_{1}\right)$, kualitas $\left(\mathrm{X}_{2}\right)$, asosiasi $\left(\mathrm{X}_{3}\right)$, dan loyalitas $\left(\mathrm{X}_{4}\right)$ terhadap keputusan pembelian (Y), disajikan pada gambar 2 .

140 | IQTISHODUNA Vol. 16 (2), 2020 http://ejournal.uin-malang.ac.id/index.php/ekonomi 


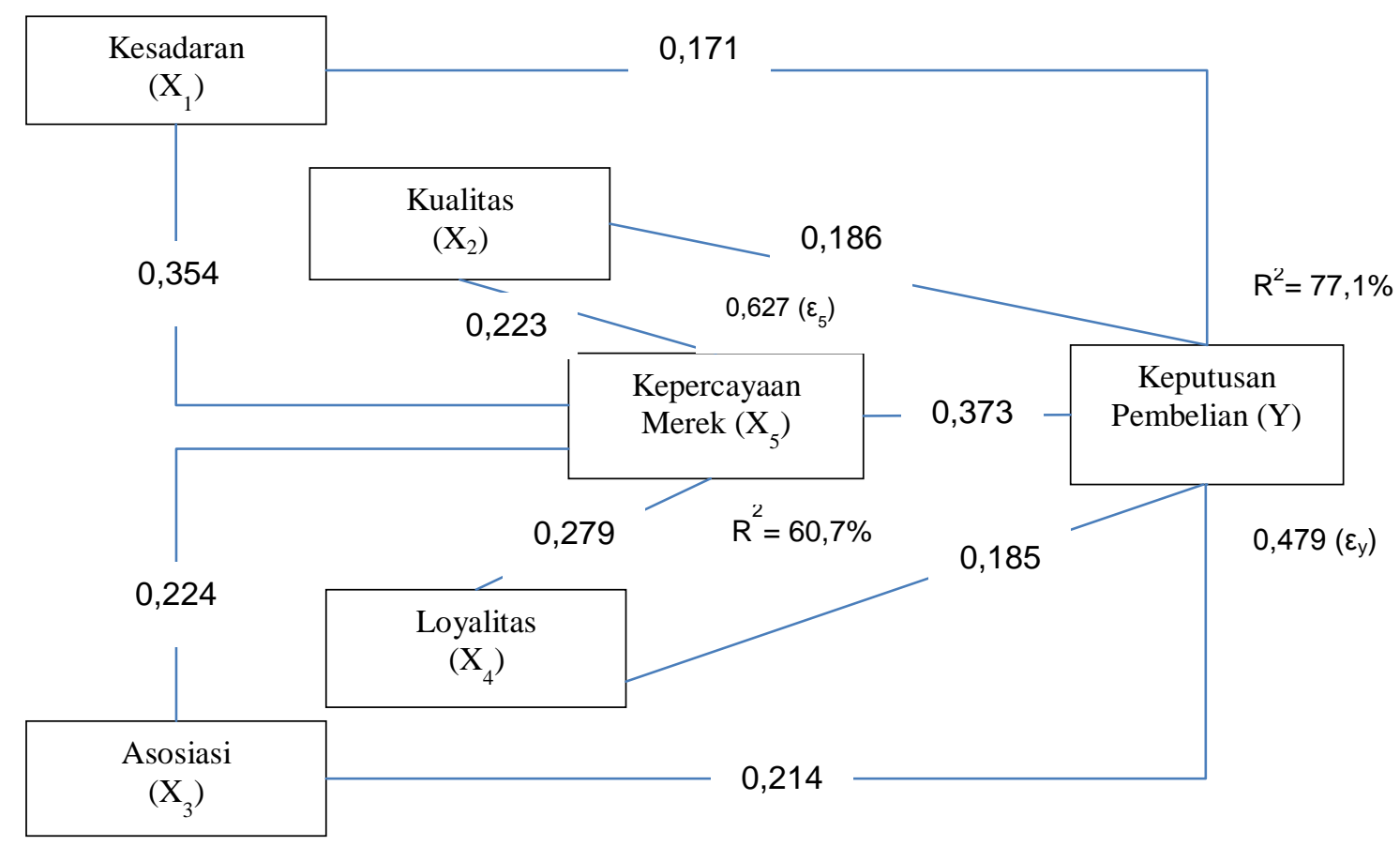

Gambar 2. Diagram Jalur Hubungan Kausal

Efek langsung (direct effect) meliputi kesadaran terhadap keputusan pembelian dengan koefisien regresi parsial sebesar 0,171; kualitas terhadap keputusan pembelian dengan koefisien regresi parsial sebesar 0,186; asosiasi terhadap keputusan pembelian dengan koefisiensi parsial sebesar 0,214; dan loyalitas terhadap keputusan pembelian sebesar 0,185. Efek intervening adalah efek tidak langsung (indirect effect) akibat dimasukkannya (introduksi) variabel intervening diantara jalur (path) hubungan kesadaran, kualitas, asosiasi, dan loyalitas terhadap keputusan pembelian. Pada gambar di atas nampak besaran pengaruh pada jalur antara variabel bebas terhadap variabel terikat melalui variabel intervening (kepercayaan merek). Besarnya pengaruh langsung dan tidak langsung variabel bebas terhadap variabel terikat melalui variabel kepercayaan merek disajikan pada Tabel 2.

Tabel 2. Analisis Hipotesis Pengaruh Langsung dan Pengaruh Tidak Langsung

\begin{tabular}{lcccc}
\hline Pengaruh Variabel & \multicolumn{2}{c}{ Pengaruh Langsung } & $\begin{array}{c}\text { Pengaruh Tidak } \\
\text { Langsung }\end{array}$ & $\begin{array}{c}\text { Pengaruh } \\
\text { Total }\end{array}$ \\
\hline $\mathbf{X}_{\mathbf{5}} \rightarrow \mathbf{Y}$ & & 0,373 & & \\
\hline $\mathbf{X}_{\mathbf{1}} \rightarrow \mathbf{X}_{\mathbf{5}} \rightarrow \mathbf{Y}$ & 0,171 & 0,354 & 0,132 & 0,303 \\
\hline $\mathbf{X}_{\mathbf{2}} \rightarrow \mathbf{X}_{\mathbf{5}} \rightarrow \mathbf{Y}$ & 0,186 & 0,223 & 0,083 & 0,269 \\
\hline $\mathbf{X}_{\mathbf{3}} \rightarrow \mathbf{X}_{\mathbf{5}} \rightarrow \mathbf{Y}$ & 0,214 & 0,224 & 0,084 & 0,298 \\
\hline $\mathbf{X}_{\mathbf{4}} \rightarrow \mathbf{X}_{\mathbf{5}} \rightarrow \mathbf{Y}$ & 0,185 & 0,279 & 0,104 & 0,289 \\
\hline
\end{tabular}


Tabel 2 diperoleh hasil antara lain: (1) variabel kesadaran berpengaruh terhadap keputusan pembelian melalui kepercayaan merek sebesar 30,3\%; (2) variabel kualitas berpengaruh terhadap keputusan pembelian melalui kepercayaan merek sebesar 26,9\%; (3) variabel asosiasi berpengaruh terhadap keputusan pembelian melalui kepercayaan merek sebesar 29,8\%; dan (4) variabel loyalitas berpengaruh terhadap keputusan pembelian melalui kepercayaan merek sebesar 28,9\%. Sedangkan uji kesesuaian model koefisien determinasi yaitu:

$$
\begin{aligned}
\mathrm{R}^{2} \mathrm{~m} & =1-\left(1-\mathrm{R}^{2} 1\right) \cdot\left(1-\mathrm{R}^{2}\right) \\
& =1-(1-0,607) \cdot(1-0,771) \\
& =1-(0,393) \cdot(0,229) \\
& =1-0,090 \\
& =0,91
\end{aligned}
$$

Hasil perhitungan model koefisien determinasi total sebesar 0,91 menunjukkan bahwa korelasi atau hubungan antara variabel bebas dengan variabel terikat adalah kuat. Definisi "kuat" karena angka di atas 0,5. Hal ini berarti $91 \%$ variasi dari keputusan pembelian dijelaskan oleh variasi dari variabel bebas sedangkan sisanya sebesar 9\% dijelaskan oleh variabel lain diluar model penelitian ini. Koefisien jalur kesadaran $\left(\mathrm{X}_{1}\right)$, kualitas $\left(\mathrm{X}_{2}\right)$, asosisasi $\left(\mathrm{X}_{3}\right)$, loyalitas $\left(\mathrm{X}_{4}\right)$ dan kepercayaan merek $\left(\mathrm{X}_{5}\right)$ terhadap keputusan pembelian (Y) dapat dijabarkan sebagai berikut.

\section{Koefisien Jalur Kesadaran Terhadap Keputusan Pembelian Melalui Kepercayaan Merek}

Berdasarkan analisis data koefisien jalur variabel kesadaran terhadap kepercayaan merek dan keputusan pembelian diperoleh hasil bahwa ada pengaruh positif signifikan sebesar 0,000 dan 0,040, dimana 0,000 dan 0,040 $<0,05$. Hasil penelitian ini sesuai dengan penelitian Rachmansyah (2010) \& Barus (2015) yang menyatakan bahwa kesadaran merek berpengaruh terhadap keputusan pembelian. Kesadaran akan merek menggambarkan keberadaan merek dalam mindset konsumennya (Durianto, 2011). Kesadaran merek akan suatu produk memegang peranan yang sangat penting dalam pengambilan keputusan (Astuti \& Cahyadi, 2007). Yuan \& Wu (2008) menyatakan bahwa produk mudah untuk ditiru akan tetapi merek yang terekam dalam benak konsumen tidak dapat ditiru oleh pesaing. Kesadaran merek yang tinggi akan suatu produk sangat berdampak pada sikap terhadap merek, dan kesadaran akan merek mampu memberikan keyakinan konsumen dalam memilih suatu merek. Dari uraian hasil analisis, kajian 
empiris, dan kajian teori dapat disimpulkan bahwa keputusan pembelian dipengaruhi oleh kesadaran melalui kepercayaan merek.

\section{Koefisien Jalur Kualitas Terhadap Keputusan Pembelian Melalui Kepercayaan Merek}

Berdasarkan analisis data koefisien jalur variabel kualitas terhadap kepercayaan merek dan keputusan pembelian diperoleh hasil bahwa ada pengaruh positif signifikan sebesar 0,016 dan 0,017, dimana 0,016 dan 0,017 $<0,05$. Hasil penelitian ini sesuai dengan penelitian yang dilakukan oleh Barus (2015) yang menjelaskan bahwa keputusan pembelian dipengaruhi oleh kualitas yang dirasakan oleh konsumen. Astuti \& Cahyadi (2007) menyatakan bahwa keputusan pembelian dipengaruhi oleh rasa percaya diri pelanggan terhadap kualitas suatu produk. Sedangkan inovasi produk merupakan dimensi yang tidak berwujud dari sebuah kualitas yang mampu memberikan keuntungan (Durianto dkk., 2011). Hasil dari penelitian ini menjelaskan bahwa sebagian besar responden menyatakan bahwa kualitas produk kamera dengan merek Sony dikenal awet dan tidak mudah rusak. Berdasarkan hasil analisis, kajian empiris, dan kajian teori dapat disimpulkan bahwa keputusan pembelian dipengaruhi oleh kualitas melalui kepercayaan merek.

\section{Koefisien Jalur Asosiasi Terhadap Keputusan Pembelian Melalui Kepercayaan Merek}

Berdasarkan analisis data koefisien jalur variabel asosiasi terhadap kepercayaan merek dan keputusan pembelian diperoleh hasil bahwa ada pengaruh positif signifikan sebesar 0,013 dan 0,005, dimana 0,013 dan 0,005 $<0,05$. Hasil penelitian ini sesuai dengan penelitian Kurniawan (2010) yang menyatakan bahwa asosiasi merek berpengaruh positif signifikan terhadap keputusan pembelian. Asosiasi sendiri menjadi faktor penentu yang penting pada suatu merek produk yang dimiliki jika produk tersebut memiliki kesamaan atribut dari produk lain, selain itu asosiasi juga merupakan sebuah identitas yang menjadi penentu diferensiasi (Durianto, dkk., 2011). Hasil analisis deskriptif menjelaskan asosiasi kamera Sony yang tergabung dalam komunitas pecinta fotografi di Malang menyatakan bahwa hasil pemotretan yang dilakukan dengan menggunakan kamera Sony memiliki kualitas gambar yang lebih bagus dibandingkan dengan merk kamera lain. Berdasarkan hasil analisis, kajian empiris, dan kajian teori dapat disimpulkan bahwa keputusan pembelian dipengaruhi oleh asosiasi melalui kepercayaan merek.

IQTISHODUNA Vol. 16 (2), $2020 \mid 143$

http://ejournal.uin-malang.ac.id/index.php/ekonomi 


\section{Koefisien Jalur Loyalitas Terhadap Keputusan Pembelian Melalui Kepercayaan Merek}

Berdasarkan analisis data koefisien jalur variabel loyalitas terhadap kepercayaan merek dan keputusan pembelian diperoleh hasil bahwa ada pengaruh positif signifikan sebesar 0,004 dan 0,025, dimana 0,004 dan 0,025 $<0,05$. Hasil penelitian ini sesuai dengan penelitian yang dilakukan oleh Wijaya (2011) yang menyatakan bahwa keputusan pembelian dipengaruhi oleh loyalitas merek. Durianto, dkk. (2011) mengungkapkan bahwasanya cara untuk mengukur tingkat loyalitas konsumen akan suatu produk yaitu melalui tingkat kepuasan konsumen. Dan tingkat loyalitas konsumen akan suatu produk dapat tercermin dari ungkapan rasa percaya diri yang tinggi ketika konsumen memutuskan untuk membeli produk tersebut. Hal ini disebabkan oleh rasa kepercayaan yang tinggi, keyakinan yang sangat besar, dan ikatan yang kuat dari seorang konsumen terhadap merek produk tersebut. Dari hasil penelitian yang dilakukan konsumen setia kamera Sony yang tergabung dalam komunitas fotografi mangatakan bahwa mereka tetap menggunakan kamera Sony meskipun harganya lebih tinggi dibandingkan dengan merek lain. Berdasarkan hasil analisis, kajian empiris, dan kajian teori dapat disimpulkan bahwa keputusan pembelian dipengaruhi oleh loyalitas melalui kepercayaan merek.

\section{Kesimpulan}

Berdasarkan hasil penelitian dan pembahasan yang telah dilakukan maka dapat disimpulkan bahwa: (1) keputusan pembelian dipengaruhi oleh kesadaran melalui kepercayaan merek.; (2) keputusan pembelian dipengaruhi oleh kualitas melalui kepercayaan merek.; (3) keputusan pembelian dipengaruhi oleh asosiasi melalui kepercayaan merek.; dan (4) keputusan pembelian dipengaruhi oleh loyalitas melalui kepercayaan merek.

Hasil dari penelitian yang dilakukan diharapkan dapat memberikan manfaat bagi diri sendiri dan orang lain. Harapan dan manfaat dari penelitian ini diantaranya: (1) Bagi produsen dan distributor kamera Sony diharapkan dapat memperbaharui desain kamera Sony yang sejauh ini desain dan bentuknya selalu konstan; (b) Bagi pengguna kamera DSLR (Digital Single lens Reflex) dalam memutuskan membeli kamera didasarkanan pada kebutuhan dan pengetahuan akan kualitas dan merek dari produk yang akan dibeli; (c) Bagi peneliti selanjutnya dapat mengembangkan variabel penelitian yang mempengaruhi keputusan pembelian kamera Sony; dan (d) Keterbatasan penelitian ini adalah sampel yang digunakan hanya komunitas 
fotografi di Malang. Dan hasil dari penelitian ini pastinya akan berbeda jika penelitian dilakukan di komunitas yang lain, sehingga dapat menjadi peluang bagi peneliti yang lain untuk melakukan penelitian pada komunitas yang berbeda.

\section{Daftar Pustaka}

Aaker, D. A (2013). Brand Portofolio Strategy. New York : Free Press.

Astuti, S. W. \& Cahyadi, I. G. (2007). Pengaruh Elemen Ekuitas Merek Terhadap Rasa Percaya Diri Pelanggan di Surabaya Atas Keputusan Pembelian Sepeda Motor Honda. Majalah Ekonomi, XVII (2). Agustus 2007.

Barus. (2015). Pengaruh Ekuitas Merek Terhadap Proses Keputusan Pembelian Smartphone Blackberry (Studi Pada Mahasiswa Program S1 Jurusan Administrasi Bisnis Fakultas Ilmu Sosial dan Politik). Skripsi. Jurusan Administrasi Bisnis, Fakultas Ilmu Sosial \& Ilmu Politik, Univeritas Diponegoro.

Deka, R. E., Nurhajati., Rachma, N. (2019). Pengaruh Brand Associationdan Brand Awareness terhadap Brand Loyalty melalui Brand Trust. Jurnal Ilmu Manajemen Magister Manajemen, 4(1), 96-107.

Durianto, D., Sugiarto \& Tony, S. (2011), Strategi Menaklukkan Pasar Melalui Riset Ekuitas dan Perilaku Merek. cetakan ketiga, Jakarta: Gramedia Pustaka Utama.

Delgado, Elena. (2014). Appliciation of a Brand Trust Scale Across Product Categories: a Multigroup Invariance Analysis. European Journal of Marketing, Vol 38 Nos 5/6 pp. 573-96.

Drummond, Helga. (2003). The Darker Side of Innovation. Journal of Information Technology, 18(2), 93-101.

Kokasih, D., Fadili, A., Fadilah, N. (2013). Pengaruh Perilaku Konsumen Terhadap Keputusan Pembelian Sepeda Motor Yamaha di Dealer Arista Johar. Jurnal Manajemen, 10 (3), 1149-1159.

Kurniawan, Y. (2011). Analisis Pengaruh Ekuitas Merek Terhadap Keputusan Pembelian Konsumen (Studi Pada Konsumen Minuman Isotonik Fatigon Hydro Di Purwokerto). Skripsi. Fakultas Ekonomi Universitas Diponegoro

Morgan, R. M. and Hunt, S. D. (2004). The Commitment-Trust Theory of Relationship Marketing. Journal of Marketing, 58 (July), 20-38. 
Nugroho, F. Y. (2011). Pengaruh Citra Merek dan Kepuasan Pelanggan Terhadap Loyalitas Konsumen. Yogyakarta: Fakultas Pertanian UPN Veteran.

Rachmasyah, R. (2010). Analisa Pengaruh Brand Equity Terhadap Keputusan Pembelian Konsumen Produk Pasta Gigi Pepsodent (Studi Kasus Pada Mahasiswa Fakultas Ekonomi Reguler II UNDIP Semarang. Skripsi. FE-UNDIP.

Rofiq, A. (2005). Peranan Ekuitas Merek Terhadap Loyalitas Pelanggan Pada Industri Telepon Seluler. Jurnal Universitas Brawijaya.

Santoso, A. \& Harmoni. (2016). Pengaruh Kualitas Produk \& Ekuitas Merek Terhadap Keputusan Pembelian. Jurnal Ekuilibrium, II (1), 43-55.

Siali, F., Jiayi, P., Shakur, M. M. A., Yakob, S. A. (2016). Relationship Between Brand Equity and Consumer Purchase Decisioan; a Case of an International Brand of Footwear. International Journal of Service Management and Sustainability (IJSMS), 1(1), 58-75.

Sholahuddin. (2013). Strategi Pengembangan Produk Di Industri Media Cetak Di Indonesia (Bertahan di Tengah Persaingan dengan Media Online). BENEFIT Jurnal Manajemen dan Bisnis, 17(1), 9-17.

Solimun. (2002). Structural Equation Modeling Lisrel \& Amos. Malang: Universitas Negeri Malang.

Sugiyono. (2011). Metode Penelitian Kuantitatif, Kualitatif dan R\&D. Bandung: Afabeta.

Sumarni, M. \& Soeprihanto, J. (2010). Pengantar Bisnis (dasar-dasar ekonomi perusahaan. Yogyakarta: Liberty.

Tjahyadi, R. A. (2006). Brand Trust Dalam Konteks Loyalitas Merek: Peran Karakteristik Merek, Karakteristik Perusahaan, Dan Karakteristik Hubungan Pelanggan-Merek. Jurnal Manajemen, 6(1), 65-78.

Widhiarta, I. G. T. E. \& Wardana, I. M.. 2015. Pengaruh Ekuitas Merek Terhadap Keputusan Pembelian I Phone di Depansar. E-jurnal Manajemen Universitas Udaya, 4(4) 832-848.

Wijaya. (2011). Analisis Pengaruh Ekuitas Merek Terhadap Keputusan Pembelian Handphone Blackberry. Skripsi. UNDIP Semarang.

Yuan, Y. H. \& Wu, C. (2008). Relationship Among Experiential Marketing Experiential Value, and Customer Satisfaction. Journal of Hospital and Tourism Research 32(3), 387-410. 